\title{
CHANGES IN FOOD INDUSTRY IN POLAND UNDER THE IMPACT OF TRANSNATIONAL CORPORATIONS IN THE $21^{\text {ST }}$ CENTURY
}

\begin{abstract}
Transnational corporations (TNCs) exist as entities taking part in the globalisation process and many authors tend to consider that they decide on the fate of the world. Their operation is the key economic force driving the globalisation processes in the economic area, which they change as well. The leading significance of the transnational corporations in the globalisation of the world economy results from their economic strength and advantages related thereto. The paper aimed at presentation of the changes in food industry and its sections, taking place under the impact of the corporations. They have operated in Poland since 1995, thus long enough to make comparisons and assessments and to draw complete conclusions. The paper identifies branches of TNCs in the food industry and their key areas of interest. Between 2000 and 2015, the branches of TNCs expanded, but to a different degree in respective sections of the food industry. In sections of very high or high level of presence of corporations their share in general grew, while in sections of low level of globalisation their share, especially recently, decreased. In general, the share of TNCs had a major and, basically, positive impact on the development of the Polish food industry, its changes and growth in the significance on the international scale, especially among the European Union countries.
\end{abstract}

Keywords: transnational corporations, foreign branches, corporate globalisation, foreign direct investments, food industry sections.

JEL codes: F61, F62, L66, Q18. 


\section{Introduction}

Transnational corporations are a specific type of enterprise due to their special features and functioning, which makes them difficult to define. Besides, as stated by Zorska (2007, p. 121), "definitions of TNCs change, due to both the evolving operation of the corporations as well as the advancement of knowledge of international business and management and other fields of science".

Currently, the most frequently quoted is the UNCTAD definition (2005, p. 297), which identifies transnational corporations as "enterprises operating as (joint-stock or limited liability) companies composed of parent enterprises and foreign affiliates. A parent enterprise is defined as an enterprise that controls assets of other entities in countries other than its home country, usually by owning a certain equity capital stake".

Currently, corporations are treated in literature as having the hierarchical structure in the form of a decentralised and flexible network that requires coordination and comprises domestic organisational units and foreign affiliates as well as the cooperating business partners (Gołębiowski, 2014). Competitive advantage of TNCs is determined by: the ability to identify and create new competences and innovative solutions, speed and efficiency of combining knowledge from a variety of fields and sources and ensuring a more effective transfer and use thereof than as a result of market transactions (see Gupta and Govindarajan, 2000; Doz, Santos and Williamson, 2001; Tallman and Phene, 2007, as in: Gołębiowski, 2014).

Currently, at the beginning of the $21^{\text {st }}$ century, we are experiencing a subsequent phase of development of the world economy. This was noted by a number of authors (Koźmiński, 2017; Rosińska-Bukowska, 2012, 2014; Gołębiowski, 2014) dealing with the issues of globalisation and transnational corporations. They hold an opinion that the world has entered a new phase of globalisation processes called corporate globalisation ${ }^{1}$.

Corporate globalisation means the need to build coalitions and corporate systems that can meet the ever-increasing market demands. Enterprises need to engage in such systems as it enables them to cope with competition in the global market. This leads to the development of global business networks around the most powerful corporations. TNCs that operate in the automotive industry, such as Volkswagen and Toyota, or the electronics industry, such as Siemens, can be cited as an example.

The TNC network systems are dominant in corporate globalisation. These systems determine the forms of cooperation, force other entities to give up part

\footnotetext{
${ }^{1}$ Rosińska-Bukowska (2014) enumerates four developmental phases of globalisation processes:

- internalisation (the initial phase - birth),

- internationalisation (the development phase - growth),

- globalisation in the strict sense (the maturity phase - expansion),

- corporate globalisation (the improvement phase - saturation).
} 
of their sovereignty in exchange for improved competitiveness achieved as a result of becoming a part of the international market.

Research conducted by Rosińska-Bukowska (2014) on the largest TNCs, showed that contemporary globalisation has contributed to the introduction of significant changes in the methods of operation of transnational corporations, also in the food sector. Thus, it can be concluded that agriculture and food economy (including the food industry) have become, at an accelerated pace, a part of the globalisation processes. This leads to both positive changes and greater production effectiveness, ecological education, creation of added value to the growing global standard as well as negative ones: genetically modified crops and foods (whose health effects have not been fully tested), changes in the character of production from the quality-focussed ("bio", organic) to the quantityfocussed (aimed at maximising yield per hectare of agricultural land), etc.

In general, it can be concluded that global corporations are becoming increasingly more powerful players on the global market, in contrast to the role of countries which is declining. They are managed more effectively and in a better manner and have a huge economic potential. They develop at a much faster pace than many countries. That is why, individual countries strive for investments of the largest transnational corporations, not only by making attempts at encouraging them to locate branches within their territories.

The more and more powerful global corporations are becoming a source of strong impulses that change the development conditions. Their business systems have advanced, by means of their influence, from the micro- level to the mezzoand often even to the macroeconomic level ${ }^{2}$.

Similarly in Poland, increasing participation of global companies in production is coupled with their increased importance and impact, both on the other food industry enterprises and the whole food product market. Consequently, the presence of transnational corporations in the food economy frequently gives rise to numerous emotions and doubts, which often leads to conflicting views. On the one hand, global companies arouse interest with their methods of operation, however, they also cause concerns about various effects of their activity. TNCs change the rules of operation on the market, forcing domestic capital enterprises to undergo reorganisation and restructuring.

The impact of transnational corporations on the globalisation processes can be analysed in a number of ways, among others by defining their, direct or indirect, impact on a given sector of the economy. TNCs have a direct impact as the most important entities actively involved in the manufacturing, sales, etc. They also have an indirect impact - as highly influential players - on the behaviour of other entities, thus exerting an even stronger influence on the overall perform-

\footnotetext{
${ }^{2}$ They have an impact on regulations established by international organisations and countries, which is confirmed by analysis of their lobbying activity (Czub, 2012).
} 
ance of the globalisation process. In the food industry, there is the whole group of activities of TNCs and significant variation of the levels of globalisation in individual industry sectors. In Poland, transnational corporations in the food industry have been operating since 1995. This allows for drawing comparisons and deeper conclusions from assessments of the globalisation processes that have taken place in this industry sector in the $21^{\text {st }}$ century.

\section{Research methodology}

It was assumed in this article that participation of transnational corporations in the sold production of a given industry sector reflects its level of concentration, therefore, individual participants of the market or a group of them (transnational corporations in our case) have market power that allows them to control such sector. They can exert significant influence on the prices, production volume, commercial conditions, excluding their business partners from participation in the market and disciplining their rivals. In addition, the degree of concentration provides information on interdependence of the industry sector participants. Porter (1999, p. 56) states that "a progressing asymmetry between industry sector participants may enable the strongest to manipulate the others".

Production concentration may be equated with an indicator of market power (Gorynia, 2007). The higher the degree of concentration in a given industry sector, the higher the market power of individual participants. This is followed by a tendency towards oligopolistic practices.

The share of transnational corporations in the food industry sectors was determined by assigning to them individual enterprises or establishments owned by transnational corporations. The total value of their production in relation to the production of the whole industry sector constitutes the share of transnational corporations in the manufacturing of individual food industry sectors. The ratio of the share of global companies in the value of sales revenue of individual food industry sectors were used to select sectors of varied degree (level) of globalisation. i.e.:

- very high (the share of global companies is more than 60\%),

- high (more than 30-60\%),

- low (less than 30\%).

Basic source of information on the TNCs operating in our country are rankings of the largest enterprises in Poland published by Rzeczpospolita daily (Top 500 and Top 2000 Rankings) and Polityka magazine as well as agency information and press releases, both domestic and foreign.

The study also uses research results and statistical data of the Institute of Agricultural and Food Economics - National Research Institute (IERiGŻ-PIB) published in market reports, papers and monographs on the macroeconomic analysis of the food industry. Published and unpublished data of the Central Statistical Office (GUS) for 2000-2015 were also used. The article (due to its 
limited volume) presents only some measures and indicators characterising the evolution of changes that have taken place in the food industry sectors in Poland under the influence of transnational corporations.

\section{The history of transnational corporations' expansion into the food industry in Poland}

The years between 1995 and 2003 were dominated by enterprise acquisitions from the State Treasury financed from foreign origin resources, mainly cash. The most important reasons for the entry of transnational corporations into the food industry are as follows:

- capturing a new, highly absorbent and promising market, which up to then had been practically inaccessible for political considerations;

- a possibility to acquire large enterprises, relatively cheaply, as a rule together with their market share, organised sources of raw materials and well-known local brands;

- low production and raw material costs;

- overtaking or catching up with global competitors as regards the capture of our market.

At that point, a certain regularity emerged, namely that transnational corporations invested in sectors which during the period of transformation distinguished themselves by:

- high ability to generate profits,

- the greatest dynamics of (or the best prospects for) production development,

- great dynamics of (good prospects for) domestic market,

- high production concentration (sectors with large enterprises).

The largest inflow of FDI into the food industry occurred in 1995-1998, when it amounted to USD 3.1 billion, which accounted for $50 \%$ of the total sum of FDI inflow in the years 1995-2004. Later, investors concentrated on the restructuring and modernisation of the acquired enterprises (Chechelski, 2008).

Another increase in the inflow of foreign direct investment into Poland, including the food industry, is mainly related to the integration of Poland with the EU. Therefore, the factors that became important for TNCs included:

- lower comparative costs of production (in particular labour costs);

- the fact that conducting business in Poland is safer (economic and political stability);

- much faster development of Polish economy (and the food industry) than in the other EU countries;

- more favourable conditions for investing in Poland thanks to changes in legislation introduced in 2004 and 2005;

- a rapid increase in demand for food in the domestic market;

- lifting of customs barriers on food exports to the European Union countries;

- obtaining export subsidies. 
Global economic crisis slowed this process down. The food industry remained, however, within the scope of interest of global companies. The process of FDI inflow started a new phase. The value of these investments depended not on the resources provided by the new investors, but those from the existing investors. These continued to be resources flowing from the headquarters of TNCs and designated for greenfield strategic investments or enterprise acquisition, but also the amounts generated by affiliates supplying the streams of FDI in the form of reinvested earnings.

The increased inflow of FDI into the food industry which was noted in recent years results from the fact that TNCs probably did not expect Polish food to be so highly valued by consumers from other European Union countries. This may act as an additional factor for production capacity development, which will lead to increased exports by TNCs.

\section{Transnational corporations in the Polish food industry}

At the time of Poland's accession to the European Union, there were approximately 60 transnational corporations operating in the food industry, in 2015, however, this number declined slightly ${ }^{3}$. During this period, part of TNCs withdrew from manufacturing activity in Poland, such as e.g.: Orkla Foods, British Sugar Overseas, Arla Foods, etc., while others were combined through mergers or acquisitions on the global market. The most spectacular takeovers were in the sugar industry, where American Kraft Foods purchased British Cadbury Schweppes, and then split into a part comprising the production of Mondelez sweets and snacks and Kraft Foods coffee. In 2015, the latter merged with Sara Lee Douwe Egberts to form Jacobs Douwe Egberts, and Mars took control over Wirgley. In the tobacco industry, on the other hand, Imperial Tobacco merged with Altadis, BAT with Scandinavian Tobacco, and Japan Tabacco with Gallaher. The global trends to concentrate production in the largest transnational corporations have also translated into our market (affiliates). The following new large corporations made their début on the Polish market in 2005-2016: Japan Tabacco and Lotte, McCormick, Müller, Marine Harvest, Stock Spirits, Barry Callebaut Manufacturing, Shuanghui J.H. Ltd. (Smithfield Foods). The largest investment in 2016 was the purchase of SABMiller branch in Poland by Japan's Asahi (for PLN 10.5 billion).

The largest global corporations operate in the Polish food industry. As many as eight out of ten the largest transnational corporations that operate in this sector and are listed in the Fortune 500 ranking have their branches in Poland. Looking at this phenomenon from geographical perspective, one may conclude that nearly all of the largest transnational corporations from Europe and North America are present in Poland. Asian transnational corporations operating on our market include: Japan Tobacco, Lotte, Asahi, India's Tata Group, Israel's Elite and China's Shuanghui J.H. Ltd.

\footnotetext{
${ }^{3}$ A detailed list of TNCs including sector affiliation and changes over subsequent years can be found in an article by Chechelski (2016).
} 
The largest transnational corporations Nestle, PepsiCo, Unilever, Danone, Mars have their branches in several sectors of the Polish food industry.

\section{Transnational corporations in developing the structure of the food industry sector ${ }^{4}$}

The share of global companies in the value of sales revenue in individual food industry sectors in Poland is presented for the years 2003, 2005, 2007, 2011 and 2015 (Table 1). These years have been selected on purpose, as they illustrate the situation before Poland's accession to the EU (2003), after the accession (2005), before the global crisis (2007) and during the economic downturn (2011). Significant changes were made during this time in the food industry, in such areas as manufacturing, sales, export, etc. It is, therefore, important to compare the share of transnational corporations before the occurrence of changes caused by these events and after. Very highly-globalised food industry sectors include: since 2003 - the tobacco, brewery, sugar, confectionery sectors; since 2012 - the oil sector; and since 2011 - the alcohol sector. On the other hand, highly-globalised industry sectors include: the non-alcoholic beverages sector, animal feed sector, food concentrates sector, and since 2015 - the fish sector. The other industry sectors can be referred to as lowly-globalised industry sectors. The wine and bakery industry sectors were not included in the classification due to lack of global companies.

In very highly-globalised industry sectors, the share of transnational corporations in revenue did not change much in 2003-2015. Changes in the tobacco, brewery, sugar and oil industry sectors were by approximately $4-8 \%$. One should not expect any significant changes in these industry sectors in the coming years, as they have been dominated by 3-4 largest world's transnational corporations in a given sector. It is possible, however, to notice oligopolistic practices, in particular in the tobacco, brewery and sugar industry sectors. In recent years, the biggest changes have taken place in the alcohol industry, where the share of transnational corporations increased by approximately 50\%, mainly through the acquisition of existing companies by TNCs.

On the other hand, a 15-20\% growth was noted in highly-globalised sectors, i.e. in the fish, animal food and non-alcoholic beverages industry sectors. These were a result of subsequent takeovers of Polish enterprises or the entry of new TNCs into a given sector, but also a result of organic growth, i.e. restructuring, modernisation and consolidation of the acquired enterprises. A decline in the TNCs' share in the food concentrates industry in 2007 was caused by changes in the Polish classification of economic activity (PKD) as regards the classification of entities.

\footnotetext{
${ }^{4}$ The study conducted in 2016 by Bisnode Polska shows that food products manufacturing is dominated by foreign entities, whose production amounts to 70\% (Mazurkiewicz, 2017), however, not all foreign entities are TNCs. The studies conducted by the author show that in 2015 transnational corporations had approximately $50 \%$ share in our food industry.
} 
Table 1

Share of transnational corporations in the value of sales revenue of individual sectors of the food industry in Poland ${ }^{a}$

\begin{tabular}{|c|c|c|c|c|c|}
\hline \multirow{2}{*}{ Industry sectors } & \multicolumn{5}{|c|}{ Percentage share of TNCs in revenues earned by the industry sector } \\
\hline & 2003 & 2005 & 2007 & 2011 & 2015 \\
\hline \multicolumn{6}{|c|}{ Very highly-globalised industry sectors } \\
\hline Tobacco & 94.9 & 97.2 & 97.1 & 99.3 & 99.2 \\
\hline Brewing & 82.8 & 83.5 & 84.6 & 86.4 & 87.4 \\
\hline Alcohol & 18.1 & 46.6 & 49.3 & 67.6 & 72.8 \\
\hline Confectionery & 73.3 & 72.3 & 72.5 & 72.6 & 69.2 \\
\hline Oil & 55.4 & 56.4 & 56.5 & 58.3 & 63.2 \\
\hline Sugar & 60.7 & 60.1 & 61.4 & 61.9 & 60.2 \\
\hline \multicolumn{6}{|c|}{ Highly-globalised industry sectors } \\
\hline Non-alcoholic beverages & 32.3 & 46.1 & 49.0 & 51.2 & 55.0 \\
\hline Animal feed & 31.8 & 32.1 & 34.8 & 48.6 & 51.3 \\
\hline Food concentrates & 66.8 & 68.1 & 39.1 & 43.4 & 45.5 \\
\hline Fish & 7.0 & 5.6 & 3.6 & 4.2 & 31.8 \\
\hline \multicolumn{6}{|c|}{ Lowly-globalised industry sectors } \\
\hline Fruit and vegetable & 8.3 & 19.5 & 20.4 & 20.8 & 18.2 \\
\hline Dairy & 12.0 & 14.4 & 15.3 & 17.9 & 15.2 \\
\hline Meat & 15.7 & 13.8 & 12.8 & 17.5 & 16.4 \\
\hline Milling & 11.4 & 13.5 & 10.8 & 10.1 & 10.8 \\
\hline
\end{tabular}

${ }^{a}$ Companies that provide financial reporting (on the basis of F-01 reports). The bakery and wine industries with no TNCs were not taken into account.

Source: own work.

A different trend can be observed in sectors characterised by a low level of globalisation. As early as in 2011 , a share of TNCs in the food industry sectors, amounted to $17.9 \%$ in the daily industry sector, $20.8 \%$ in the fruit and vegetable sector and $17.5 \%$ in the meat sector. In recent years, their share has been declining. In 2015 , their share was $15.3,18.2$ and $16.1 \%$, respectively.

The decline is due to several factors:

- Numerous large- and medium-sized companies with domestic capital were established in these sectors. They can oppose the activity of corporations, operate on lower margins offering the consumers products of comparable quality at lower prices. TNCs operate on higher margins, that is why they are encountering stronger and stronger competition on the part of large domestic companies and their development is not so dynamic as previously Frequently, in order to maintain higher margins, they liquidate less profitable establishments, as is the case in the dairy industry for example (Wieczorkiewicz, 2015). 
- According to consumer surveys, a strong asset for Polish companies in these sectors is patriotic behaviour of a large part of Polish society which demonstrates itself when they buy products. Poles prefer to buy products made in Poland, in particular when they are cheaper and of comparable quality. It must be pointed out, however, that these conclusions do not apply to all TNCs (Mazurkiewicz, 2017).

- In sectors characterised by low share of TNCs, the increase in production was higher in recent years than in most sectors dominated by TNCs, which resulted, given the insignificant increases in corporate production in these sectors, in a higher share of Polish companies in the structure of such sectors.

- In such sectors there are many small-, medium- and large-sized enterprises, which are not large enough, however, to make transnational corporations interested in their acquisition, while the dairy industry, where there are large enterprises, is dominated by cooperatives characterised by dispersed share ownership.

Summing up, in 2000-2015, the share of TNCs in revenue generated by the food industry sectors characterised by a very high and high share of such corporations increased, while a decrease was noted in industry sectors characterised by a low share of TNCs. It can be stated, therefore, that corporations have further strengthened their advantage in industry sectors in which they already had a strong position.

Share of very highly-globalised industry sectors in the structure of Polish food industry decreased during the analysed period from 27.0 to $18.7 \%$, mainly as a result of stabilisation of the value of sales in the tobacco, brewery, alcohol and oil industry sectors (caused by a variety of reasons), leading to their decreasing share in the structure of the Polish food industry (Table 2).

A growth by 4.9 p.p. was noted during this period in highly-globalised sectors. In the food concentrates industry (in the first period), this was a result of changes in the Polish classification of economic activities (PKD), and after 2007 - an increase in the TNCs' manufacturing resulting from organic development, similarly as in the non-alcoholic beverages industry. In the fish industry, on the other hand, sales of the largest Polish company Morpol, Norwegian corporation and a rapid development of Frosta i Müller establishments as well as the entry of new corporations Espressen and Suempol caused a dynamic growth of the share of TNCs in this industry sector.

Lowly-globalised industry sectors noted an increase by 3.4 p.p. This is a result of an increase by 5.9 p.p. of the meat and poultry industry in the food industry structure.

Summing up, it can be concluded that in 2000-2015, transnational corporations had an impact on changes in the structure of the Polish food industry sectors. Therefore, the structure of our food industry is becoming more and more similar to the structure of the EU food industry, while in many sectors it is nearly identical. 
Table 2

Percentage changes to the structure of production sold by sectors in the selected sectors of the food industry

\begin{tabular}{|c|c|c|c|}
\hline Industry sectors & 2000 & 2015 & Percentage point changes $2015 / 2000$ \\
\hline \multicolumn{4}{|c|}{ Very highly-globalised industry sectors } \\
\hline Tobacco & 4.75 & 2.47 & -2.28 \\
\hline Brewing $^{\mathrm{a}}$ & 6.46 & 4.36 & -2.10 \\
\hline Alcohol & 2.11 & 1.91 & -0.20 \\
\hline Confectionery & 6.14 & 5.75 & -0.39 \\
\hline Oil & 2.57 & 2.27 & -0.30 \\
\hline Sugar & 5.00 & 1.93 & -3.07 \\
\hline Total & 27.0 & 18.7 & \\
\hline \multicolumn{4}{|c|}{ Highly-globalised industry sectors } \\
\hline Non-alcoholic beverages & 4.20 & 3.91 & -0.29 \\
\hline Animal feed & 6.87 & 7.90 & 1.03 \\
\hline Food concentrates ${ }^{\mathrm{b}}$ & 6.42 & 7.97 & 1.55 \\
\hline Fish & 2.29 & 4.89 & 2.60 \\
\hline Total & 19.8 & 24.7 & \\
\hline \multicolumn{4}{|c|}{ Lowly-globalised industry sectors } \\
\hline Fruit and vegetable ${ }^{c}$ & 9.05 & 8.27 & -0.78 \\
\hline Dairy $^{d}$ & 14.50 & 13.89 & -0.61 \\
\hline Meat and poultry & 25.47 & 31.37 & 5.90 \\
\hline Cereal and milling ${ }^{\mathrm{e}}$ & 4.17 & 3.13 & -1.04 \\
\hline Total & 53.2 & 56.6 & \\
\hline Total & 100.00 & 100.00 & \\
\hline
\end{tabular}

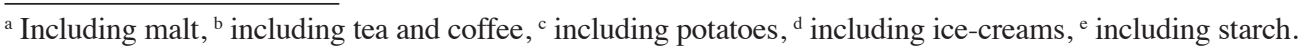
Source: own calculations on the basis of GUS (2002-2015).

\section{Impact of transnational corporations on production, employment and labour productivity}

In the $21^{\text {st }}$ century, the Polish food industry was one of the fastest-growing processing sectors in the EU. In 2001-2014, the average growth rate of the value of production sold in this sector (at current prices) was $5.7 \%$ annually, while the average for EU-28 was $2.5 \%$ and for EU-15 - 2.2\%. At that time, the Polish food industry increased its share in the food industry production from $6.4 \%$ to $8.5 \%$ and became the $6^{\text {th }}$ food producer in the EU.

Over the years 2000-2015, the value of sold production in the food industry increased by $217.9 \%$, while production in very highly-globalised industry sectors increased by $161.0 \%$, in highly-globalised industry sectors by $290.5 \%$ and 
in lowly-globalised industry sectors by $247.2 \%$. The fastest production growth rate was noted in the following industry sectors: the fish sector by $398 \%$, the food concentrates sector by $189 \%$, the meat and poultry sector by $187 \%$ and the animal feed sector by $168 \%$, while the slowest rate was noted in: the sugar sector, where it dropped by $-10 \%$, in the tobacco sector, where it increased by $21 \%$, in the brewery sector by $57 \%$ and in the cereal and milling sector by $75 \%$. Changes in the production growth rate occurring in individual sectors are caused by a number of factors, e.g.: changes in the structure of consumption, export directions, incomes of local people, etc. Another aspect is the influence of transnational corporations, which may have an impact through increased capital expenditures, export volume, advertising and marketing expenditures. They are also the main driving force of changes in consumer behaviour and, therefore, the model of consumption.

The value of production of the industry sector in the analysed period was steadily increasing in all the sectors, although the rate of changes in individual sectors was different. At the beginning of the $20^{\text {th }}$ century, the fastest production growth was noted in the brewery, sugar and non-alcoholic beverages sectors. At present, the fastest-growing sectors include: the fish, meat and poultry, and the animal feed sectors.

Mencinger (2003) points out that positive effects of the inflow of TNCs were not noted in all the developing countries. Long-term benefits for the economy of foreign direct investment depend on the ability of domestic companies to adapt innovations applied in international corporations as well as on their ability to compete with foreign enterprises for position in global supply chains. The inflow of TNCs does not necessarily have to positively impact the development of the sector into which the investments flow. On the contrary, if domestic companies are very weak, international corporations may leads to their closing down, and thus to a decline in economic potential. In the case of Polish food industry, a reaction to the presence of TNCs may be positive, because production growth was noted both in the very highly-, highly- as well as in the lowly-globalised industry sectors.

Employment. In 2000-2015, most of the analysed food industry sectors noted a decrease in employment (Table 4). The largest decrease in employment occurred in very highly-globalised sectors of the food industry, and in particular in the sugar industry by 17.3 thousand employees, i.e. by nearly $-84 \%$ of the level noted in $2000^{5}$, as well as in the tobacco industry, which noted a decrease by $-42.6 \%$, the brewery industry - by $-41.7 \%$, the non-alcoholic beverages industry - by $-40.1 \%$. A relatively large decrease in employment also occurred in

\footnotetext{
${ }^{5}$ This was a consequence of liquidation of a large number of small sugar-refineries. At present, there are 18 sugar-refineries grouped under 4 companies, while in 2000 , there were 74 sugar-refineries.
} 
the dairy industry - by $-31.4 \%$, the fruit and vegetable industry - by $-21.4 \%$ and the cereal and milling industry - by $17.9 \%$, thus in the lowly-globalised sectors, which may be indicative of a tendency visible in the whole food industry to replace employment with fixed assets. On the other hand, employment increased in: the food concentrates industry - by $53.1 \%$ (because of changes in the Polish classification of activities (PKD)), the fish industry - by $33.1 \%$, the animal feed industry - by $14 \%$ and in the meat and poultry industry - by $7.9 \%$, as a result of a large increase in the production value noted during this time in these sectors. Decrease in the level of employment in individual sectors of the food industry differed in terms of the course and scale. It depended on the strategies of transnational corporations and enterprises adapting to changing conditions of both the domestic and global environment.

Assessing the impact of transnational corporations on employment in the Polish food industry, it can be concluded that:

- They largery contributed to elimination rather than creation of jobs.

- Differences were noted in terms of the course and scale of elimination of jobs in individual industry sectors.

- Apart from quantitative effects, TNCs also contributed to favourable qualitative changes, as corporations take care to improve the qualifications of their employees. Changes in qualifications and the transfer of work styles mostly take place through the introduction of the work models and requirements adopted from the entire corporation.

- Corporations created better working conditions, e.g. they provided machines, complied with the $\mathrm{OH} \& \mathrm{~S}$ regulations, etc.

- Employees of transnational corporations are remunerated better than in most domestic capital enterprises.

- In addition, employees of transnational corporations had an opportunity to learn job skills and gain experience through job rotation in different countries. During the initial stage, the percentage of foreigners among TNCs management board members was very high and decreased with time when Poles gained experience. At present, there are more and more Polish nationals in TNCs management boards. Besides, more and more Poles employed in corporations decide to set up their own business or are appointed managers in domestic enterprises (using experience gained in TNCs).

Thus, the spillover effect occurs, i.e. imitation and the flow of information and knowledge into domestic capital enterprises. 


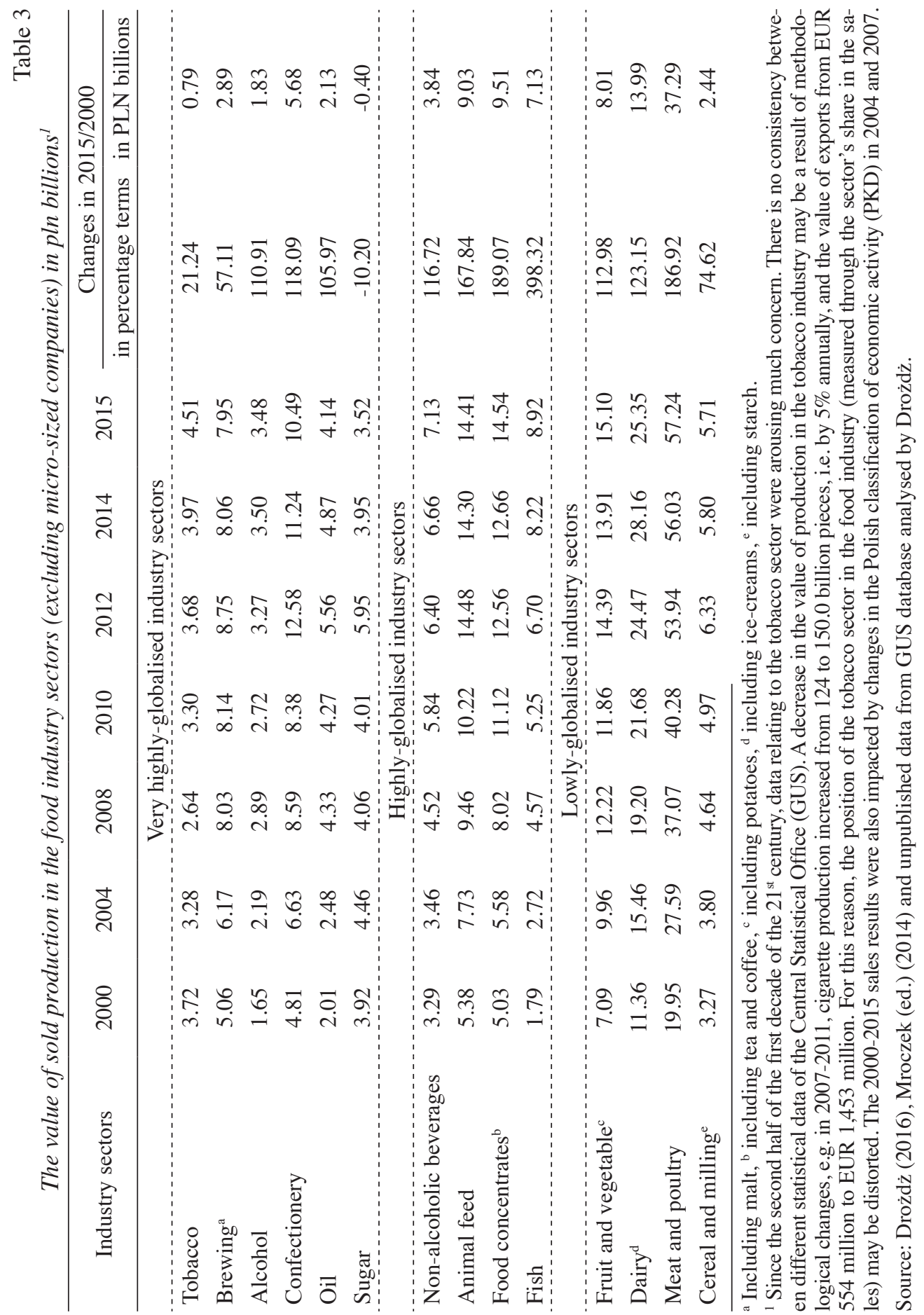




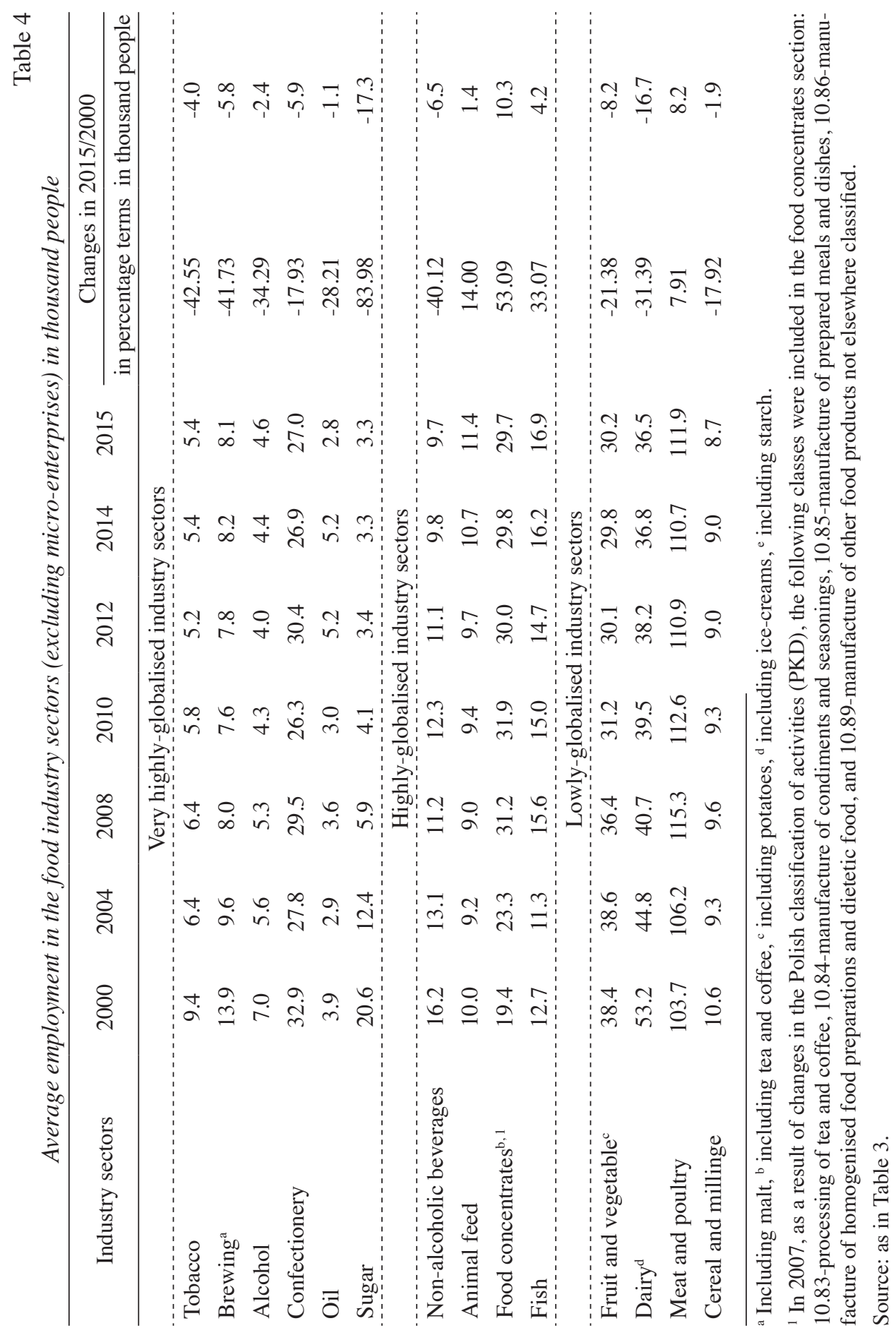


Labour productivity. In the practice of labour productivity measurement, added value is considered to be one of the most objective categories of assessing enterprise efficiency, widely used for the purpose of labour productivity assessment. Its nature and importance mainly lies in the fact that it measures productivity in terms of the values brought in by human capital in relation to external material costs. Thus, it is an important criterion of an ability to generate value for the owners (Gołaś, 2010).

In 2000-2015 (Table 5), the highest level of labour productivity was noted in the highly-globalised sectors of the food industry, such as the alcohol sector (PLN 382.3 thousand/employee), the sugar sector (PLN 330.5 thousand/employee), the brewery sector (PLN 311.3 thousand/employee) and the tobacco sector (PLN 262.4 thousand/employee). The lowest level of labour productivity was noted in lowly-globalised industry sectors, and in particular in the meat and poultry and dairy industry sectors (PLN 79.4 and 99.6 thousand/employee, respectively). On the other hand, as regards the percentage change of labour productivity in the analysed years, the highest values were reached in the following industry sectors: the alcohol sector $-393 \%$, the sugar sector $-269 \%$, the fish sector $-286 \%$ and the non-alcoholic beverages sector $-240 \%$. Lowly-globalised industry sectors, i.e. the fruit and vegetable sector, the meat and poultry sector and the dairy sector also achieved a high growth rate of labour productivity: 174,158 and $140 \%$, respectively. In 2000, however, these industry sectors began at a significantly lower level.

Taking into account the absolute values, more favourable changes in labour productivity definitely occurred in very highly-globalised sectors of the food industry.

Slightly fewer differences in labour productivity were observed in individual sectors of the food industry in the analysed years. In 2000, there were differences between sectors characterised by the highest and the lowest labour productivity of 5.05 times and in 2015 of 4.81 times. Factors responsible for increase in labour productivity in individual sectors of the food industry were different as well ${ }^{6}$. In sectors with high foreign capital share, a strong reduction was noted in the employment rate and a high increase in technical employment infrastructure. Sectors with a low share of TNCs were characterised by a higher rate of production increase and lower reduction in employment rate (with the exception of the dairy industry).

\footnotetext{
${ }^{6}$ The growth rate of labour productivity depends on a number of factors, such as e.g. specific character of the sector, market regulations, production concentration, economic situation, technical employment infrastructure, human labour inputs and possibilities of substituting it with objectified labour, amount of remuneration and bonus systems (Mroczek (ed.), 2014).
} 


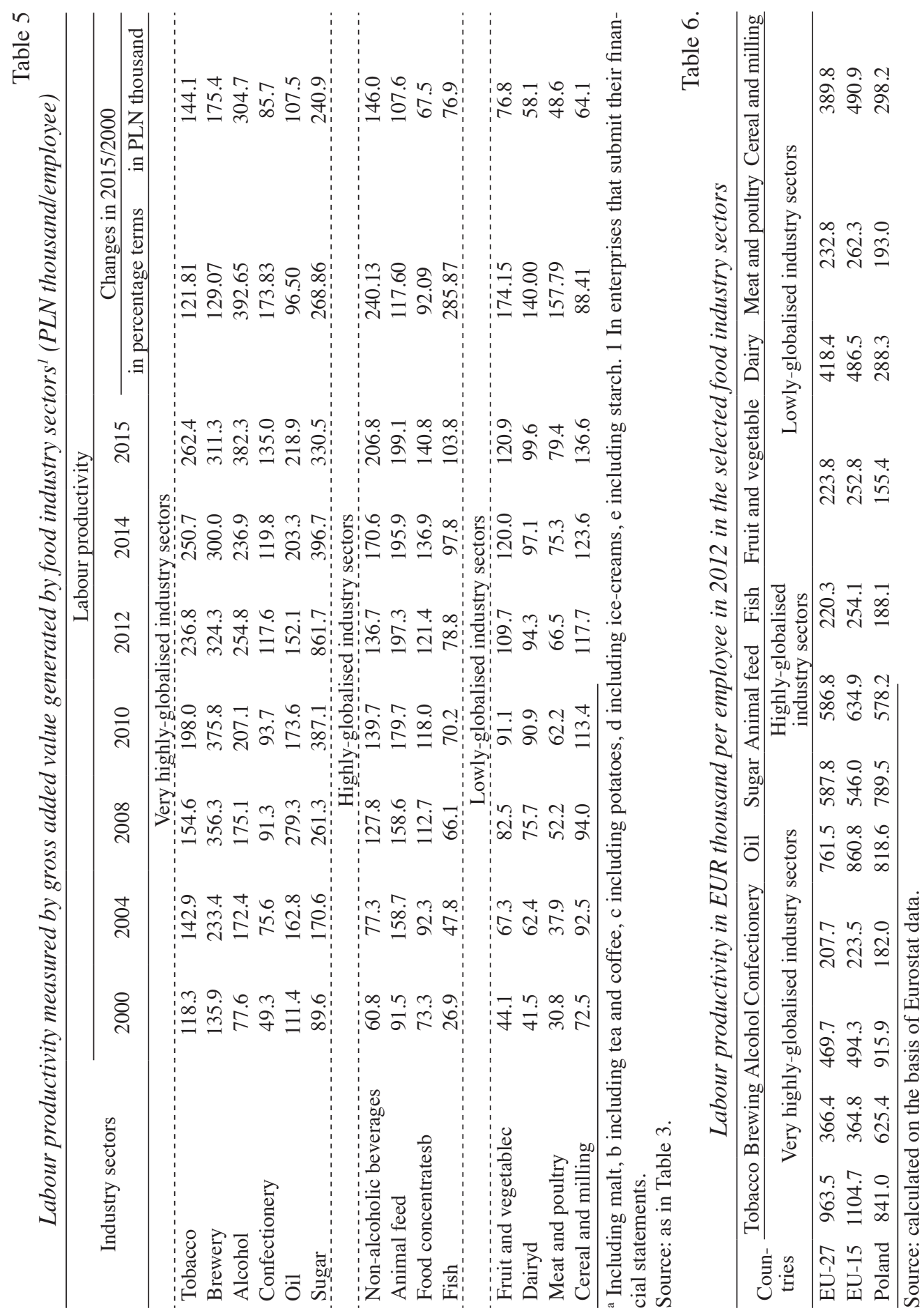


In most sectors of the food industry, in particular in sectors with the high share of TNCs, the labour productivity growth rate was higher than the sold production dynamics. This is an indicator of increased international competitiveness of the Polish food industry. This mainly applies to the highly-globalised sectors of the food industry, where labour productivity at comparable prices (in accordance with the 2012 Eurostat data) was higher in Poland not only than the average for EU-27, but also the average for EU-15. For example, in the brewery industry, average labour productivity per employee (in EUR thousand) was higher by $70.6 \%$ than in EU-27 and $71.4 \%$ than in EU-15 respectively, similarly in the alcohol industry - by 95.0 and $85.3 \%$ and the sugar industry 34.3 and $44.6 \%$ (Table 6).

Summing up, labour productivity growth occurred in 2000-2015 in all sectors of the food industry, while the highest growth rate of labour productivity took place in the sectors of the food industry characterised by a large share of TNCs. Hence, it may be concluded that transnational corporations increase the efficiency of labour utilisation faster than other enterprises, thus having a significant impact on both the development and efficiency of individual sectors, and therefore, the whole food industry in Poland.

\section{Conclusions}

The analysis of the operation of transnational corporations leads to a varied assessment of their impact on the Polish food industry. The strongest positive impact of the operation of TNCs mostly concerned the transformation process, development of the competitive market and internationalisation of economic activity. Involvement in the transformation was mainly conducive to the interests of the corporations themselves, as they have become the largest companies in the Polish market dealing with the sale of food products. This is a evidenced by a very high share of TNCs in the manufacturing process in some sectors of the food industry. The thorough restructuring and modernisation of the acquired Polish enterprises have brought rapid results in terms of increasing their competitive advantage and strengthening their position on the Polish market.

Polish food producers are more and more often encountering competition on the part of transnational corporations. The enormous growing potential and great opportunities of transnational corporations are a consequence of the availability of such key resources as state-of-the-art technologies, huge and mobile capital as well as well-known product brands and developed distribution networks that ensure easy access to the market. The political power of transnational corporations is also growing, they are exerting stronger and stronger impact on the governments and non-governmental organisations. The basic directions and development trends on the food markets are also mainly determined by global companies.

Growing concentration of entities both limits the number of participants and aims at the simplification and elimination of all types of activities that result in 
increased costs. This type of activity is mainly inspired by corporations. Because of that, we are more and more often experiencing in our food economy the unfavourable oligopolistic practices implemented by transnational corporations dealing with manufacturing. That is why, more and more domestic capital enterprises decides to enter into cooperation with transnational corporations. This is so despite the fact that they operate at high margins and impose, at the same time, the lowest prices on their suppliers. Another limitation to the independence of smaller companies is production commissioned by global trading companies under their brands. There is little competition between trading corporations, while subcontractors compete vigorously. As a result, global corporations derive the most benefits (economic surplus) from the whole production and trading process (monopsony).

Smaller companies, unless they find a suitable market niche, are forced to adapt to such conditions. Their role is often reduced to the role of a subcontractor. Production for the network involves, of course, serial production and specialisation, it causes, however, a kind of incapacitation and makes the producer dependent on a single recipient that imposes contractual conditions. This can be referred to as corporate globalisation. On the other hand, no greater cooperation between production TNCs and domestic enterprises operating in the food industry sector was observed.

Given the above-mentioned conditions, it can be concluded that one of the main threats of globalisation for enterprises that operate in the food industry is the problem of fighting competition in the domestic and foreign market and gaining advantage over other enterprises operating in the same sectors. That is why, the process of concentration will be continued in the food industry, and large companies, including transnational corporations, will gain in importance. The position of micro-, small-sized and a large number of mediumsized enterprises, which are less capable of overcoming the non-economic barriers to entry and participation in the global market, will gradually decline. They will remain, however, a permanent component of the structure of the Polish food industry.

In addition to unfavourable activities, transnational corporations also have a number of positive effects on our food economy. They are, inter alia, as follows:

- capital inflow which contributes to the modernisation of trade and food industry;

- knowledge flow, innovation;

- wider range of products offer in the food market;

- favourable changes in employment - higher pay and qualifications in the branches of TNCs have a positive impact on the whole economy;

- a large part of Polish exports of agri-food products is carried out by manufacturing and trading corporations;

- increase in revenue of the national budget; 
- contribution to reducing food prices;

- exerting a positive impact on competitors, both in the food products manufacturing and trading sector, thus improving the effectiveness of the whole food industry and trade;

- involvement in activity which forces other entities to consolidate.

Taking into account the research results presented in this paper as well as the assessments that cover different dimensions of the effects of globalisation processes on this industry sector, it can be concluded that their impact was beneficial and the Polish food economy of the 2000-2015 period can be seen as a group benefiting from globalisation. This process is assessed differently in individual industry sectors owing to a varying degree of globalisation, and in addition to positive effects, there are also negative ones, in particular in the highly- and very highly-globalised sectors. 


\section{References}

Brach, J. (2015). Korporacje transnarodowe w gospodarce światowej- ocena działalności. Ekonomia XXI wieku, Economics of the $21^{\text {st }}$ century, no. 1(5), pp. 27-46.

Chechelski, P. (2008). Wpływ procesów globalizacji na polski przemyst spożywczy. Studia i Monografie, no. 145. Warszawa: IERiGŻ-PIB.

Chechelski, P. (2015). Procesy globalizacji i liberalizacji oraz ich wpływ na przemysł spożywczy. W: R. Mroczek (red.), Przemiany strukturalne przemysłu spożywczego w Polsce i UE na tle wybranych elementów otoczenia zewnętrznego. Monografie Programu Wieloletniego 2015-2019, no. 12 (pp. 9-27). Warszawa: IERiGŻ-PIB.

Chechelski, P. (2016). Korporacje transnarodowe w polskim przemyśle spożywczym. Przemyst Spożywczy, no. 7.

Czub, J.F. (2012). Lobbing grup biznesu w Unii Europejskiej. Warszawa: Poltex.

Drożdż, J. (2011). Analiza ekonomiczno-finansowa wybranych branż przemystu spożywczego w latach 2003-2009. Studia i Monografie, no. 151. Warszawa: IERiGŻ-PIB.

Drożdż, J. (2016). Ocena sytuacji ekonomiczno-finansowej przemysłu spożywczego w latach 2010-2014. Studia i Monografie, no. 168. Warszawa: IERiGŻ-PIB.

Gasz, M. (2012). Znaczenie korporacji transnarodowych w gospodarce światowej. Ekonomia i Prawo, t. XI, no. 4.

Gołaś, Z. (2010). Czynniki kształtujące wydajność pracy w przedsiębiorstwach przemysłu spożywczego. Zagadnienia Ekonomiki Rolnej no. 4(325), pp. 30-50.

Gołębiowski, T. (2014). Wpływ zakorzenienia przedsiębiorstwa na przewagę konkurencyjną - perspektywa korporacji transnarodowych. International Business and Global Economy, no. 33, pp. 495-505.

Gorynia, M. (2007). Niewidzialne efekty zagranicznych inwestycji. Rzeczpospolita, 23.02.2007.

Gorynia, M., Samelak, O. (2013). Przegląd badań nad funkcjonowaniem filii korporacji transnarodowych w Polsce. Gospodarka Narodowa, no. 10(266).

GUS (2002-2015). Rocznik Statystyczny Przemystu. Warszawa.

GUS (2016). Działalność gospodarcza podmiotów z kapitałem zagranicznym w $2015 \mathrm{r}$. Warszawa.

Hill, H., Jongwanich, J. (2009). Outward Foreign Direct Investment and the Financial Crisis in Developing East Asia. Asian Development Review, vol. 26, no. 2.

Kacperska, E. (2017). Rozwój przemysłu spożywczego w Polsce w aspekcie globalizacji. SERiA, Roczniki Naukowe, t. XVIII, issue 6.

Kosztowniak, A. (2015). Ekspansja korporacji transnarodowych w latach 1990-2013. Gospodarka Narodowa, listopad-grudzień, no. 6, pp. 101-128.

Koźmiński, A.K. (2017). Czwarta fala globalizacji. Rzeczpospolita, 09.05.2017.

Lech, M. (2010). Zdolność oddziaływania korporacji transnarodowych na współczesne stosunki międzynarodowe w dobie procesu globalizacji. W: J. Menkes, T. Gardocka (ed.), Korporacje transnarodowe. Jeden temat, różne spojrzenia. Warszawa: Academica SWPS.

Mazurkiewicz, P. (2017). Chcemy towarów z naszych fabryk. Rzeczpospolita, 30.07.2017.

Mencinger, J. (2003). Does Foreign Direct Investment Always Enhance Economic Growth? KYKLOS, vol. 56, no. 4. 
Mroczek, R. (red.). (2014). Procesy dostosowawcze polskiego przemysłu spożywczego do zmieniajacego się otoczenia rynkowego (1). Program Wieloletni 2011-2014, no. 117. Warszawa: IERiGŻ-PIB.

PAIiIZ (2014). Food processing sector in Poland. Retrieved from: http.//www.paiz.gov.pl (access date: 03.2017).

Porter, M.E. (1999). Strategia konkurencji. Metody analizy sektorów i konkurentów. Warszawa: PWE.

Rosińska-Bukowska, M. (2012). Rozwój globalnych sieci biznesowych jako strategia konkurencyjna korporacji transnarodowych. Łódź: Wyd. Uniwersytetu Łódzkiego, s. 38-41, pp. 179-186.

Rosińska-Bukowska, M. (2014). Procesy globalizacji i ich wpływ na gospodarkę żywnościową i rolnictwo - przez pryzmat działalności korporacji transnarodowych. Zeszyty Naukowe SGGW, Problemy Rolnictwa Światowego, t. 12(XXIX), z. 1, Warszawa, pp. 97-107.

Sowa, K. (2006). Strategie konkurencji korporacji transnarodowych. Warszawa: Difin.

UNCTAD (2005). World Investment Report. Transnational Corporation and the Internationalization of R\&D. New York-Geneva.

UNCTAD (2006). World Investment Report. FDI from Developing and Transition Economies. Implications for Development (pp. 164-173). Retrieved from: http.//unctad. org (access date: 10.02.2015).

UNCTAS (2008). World Investment Report. Transnational Corporations and Infrastructure Challenge. Retrieved from: http.//unctad.org (data dostępu: 10.03.2017).

Urban, R., Szczepaniak, I., Mroczek, R. (2010). Polski sektor żywnościowy w pierwszych latach członkostwa (Synteza). Program Wieloletni 2005-2009, no. 177, Warszawa: IERiGŻ-PIB.

Wieczorkiewicz, R. (2015). Rekonkwista. Rynek Spożywczy, no. 4.

Zorska, A. (2007). Korporacje transnarodowe. Przemiany, oddziatywanie, wyzwania. Warszawa: PWE. 
PIOTR CHECHELSKI

Instytut Ekonomiki Rolnictwa i Gospodarki Żywnościowej

- Państwowy Instytut Badawczy

Warszawa

\title{
ZMIANY ZACHODZĄCE W PRZEMYŚLE SPOŻYWCZYM W POLSCE POD WPŁYWEM KORPORACJI TRANSNARODOWYCH W XXI WIEKU
}

\begin{abstract}
Abstrakt
Korporacje transnarodowe (KTN) wystepuja jako podmioty wspóttworzace proces globalizacji, a wielu autorów skłania się do stwierdzenia, że to właśnie one obecnie decyduja o losach świata. Ich działalność stanowi bowiem główna sitę ekonomiczna, napędzajaca procesy globalizacji w sferze ekonomicznej, która też zmieniaja. Wiodace znaczenie korporacji transnarodowych $w$ globalizacji gospodarki światowej wynika zich sity gospodarczej oraz przewag, jakie sa z nimi zwiazane. Celem artykułu było przedstawienie zmian zachodzacych w przemyśle spożywczym i jego działach, dokonujacych sie pod wpływem korporacji. W Polsce prowadza one swoja dziatalność od 1995 r., a więc dostatecznie długo, aby móc dokonać porównań $i$ wyciagnać petniejsze wnioski i przeprowadzić oceny. W artykule zidentyfikowano filie KTN w przemyśle spożywczym, ich pozycję ekonomiczna oraz kluczowe działy ich zainteresowania. W latach 2000-2015 nastapit wzrost ekspansji filii korporacji. Był on jednak zróżnicowany w poszczególnych działach przemysłu spożywczego. W działach o bardzo wysokim $i$ wysokim poziomie obecności korporacji ich udziat z reguty wzrastat, natomiast $w$ działach o niskim poziomie globalizacji ich udziat, zwłaszcza w ostatnich latach, malat. Generalnie udział KTN miał duży i z reguły pozytywny wpływ na rozwój polskiego przemystu spożywczego, jego przemiany oraz wzrost znaczenia w skali międzynarodowej, a zwłaszcza wśród krajów Unii Europejskiej.
\end{abstract}

Słowa kluczowe: korporacje transnarodowe, filie zagraniczne, globalizacja korporacyjna, bezpośrednie inwestycje zagraniczne, przemysł spożywczy, działy przemysłu spożywczego.

Accepted for print: 15.12.2017.

Unless stated otherwise all the materials on the website are available under the Creative Commons Attribution 3.0 Poland license. Some rights reserved to the Institute of Agricultural and Food Economics - National Research Institute.

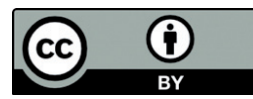

